\title{
Pendampingan Penerapan Protokol Kesehatan Di Masa Era New Normal Pada Kumpulan Pengajian Kelompok Wanita Tani Di Desa Saronggi
}

\author{
Cory Nelia Damayanti $^{1^{*}}$, Dian Ika Puspitasari ${ }^{2}$, Emdat Suprayitno $^{3}$ \\ ${ }^{1,2,3}$ Fakultas Ilmu Kesehatan Universitas Wiraraja \\ *Email : corynelia@wiraraja.ac.id
}

\begin{abstract}
Background: In 2020, Indonesia experienced a pandemic period, during which the corona virus spread. Close contact is a factor in the transmission of the covid 19 virus. Applying health protocols is considered important to reduce the incidence of the increase in the covid 19 virus. Methods: The basic purpose of this service is to provide training and assistance in implementing health protocols for community groups, especially the recitation group for farmer women's groups in the village of Saronggi. The main purpose of this service is to suppress the spread of the corona virus in the community. Results: The results showed that the counseling and mentoring process at the Women's Farmer's Association in Saronggi village went smoothly and as expected. This can be seen from the enthusiasm of all members when listening to counseling and changes in the behavior or habits of members in implementing health protocols when carrying out activities Conclusions Suggestions that we can hope for are to remain disciplined with health protocols so that they can really suppress the spread of the virus and break the chain of the Corona Virus.
\end{abstract}

Keywords: the application of health protocols; the spread of the corona virus

\section{PENDAhUluAN}

Organisasi kesehatan dunia sejak Januari 2020 telah menyatakan bahwa dunia masuk ke dalam darurat global terkait virus Covid 19 (Rosidah et al., 2020). Awal Tahun 2020 terjadi penyebaran virus covid 19 dengan gejala seperti pilek, batuk, panas tinggi, anosmia, dan badan terasa lemah. Meningkatnya penularan covid 19 sangat cepat, akibat adanya interaksi sosial secara langsung oleh masyarakat. Dengan adanya peristiwa ini maka menjadi penting untuk menjalankan protokol kesehatan dalam mencegah penularan virus tersebut. Dalam masa new normal pandemi Covid-19 terjadi perubahan pola hidup dan kebiasaan masyarakat.

Masyarakat bisa kembali beraktivitas seperti sebelumnya dengan syarat mengutamakan protokol kesehatan dan kondisi kesehataan yang baik, yang dimiliki masyarakat. Covid-19 mengubah kebiasaan perilaku sehari - hari baik di rumah, sekolah, kantor, jalan, dan dimanapun. (Thorik, 2020). Salah satu Permasalahan yang muncul dalam masa pandemi Covid-19, adalah masih rendahnya kesadaran masyarakat dalam menerapkan protokol Kesehatan (Suprayitno, 2021). Di Desa Saronggi tepatnya di Dusun Nangnangan terdapat organisasi wanita yang didalamnya terdapat kegiatan dakwah dan pengajian. Organisasi tersebut berupa kumpulan Pengajian Kelompok Wanita Tani yang jumlah anggotanya 60 orang.

Pelaksanaan kegiatan di pengajian kelompok tani tersebut dalam seminggu dilaksanakan 2 kali. Di pengajian tersebut kurang menerapkan physical distancing, ada yang tidak menggunakan masker, dan tidak tersedianya media untuk cuci tangan di tempat kegiatan. Sebagian besar anggota majeis taklim kalau dilihat dari usianya mayoritas dewasa tua, dari segi ekonomi mayoritas menengah kebawah, ibu rumah tangga dan pendidikannya mayoritas sampai pendidikan menangah, hal tersebut 
tersebut bisa menjadi factor kurangnya pemahaman dan pengetahuan tentang protocol kesehatan

\section{TINJAUAN PUSTAKA}

Pemerintah khususnya Indonesia telah mengeluarkan status darurat bencana terhitung mulai tanggal 29 Februari 2020 hingga 29 Mei 2020 terkait pandemic covid 19 ini berjumlah 91 hari (Putri et al., 2020). Ada beberapa kebijakan yang dilakukan pemerintah terkait penanganan kasus covid 19 diantaranya: mengurangi kegiatan diluar rumah, Social Distancing, wajib menggunakan Masker, meningkatkan kebiasaan mencuci tangan, Bekerja dan Belajar dari rumah, menjauhi kerumunan, PSBB (Wiranti et al., 2020). Memasuki era new normal di masa pandemi Covid-19 meningkatkan perubahan pola hidup dan imunitas yang ada di masyarakat. Masyarakat bisa kembali beraktivitas seperti sebelum adanya pandemi, dengan syarat tetap disiplin menggunakan protokol kesehatan dan imunitas yang dimiliki masing-masing masyarakat harus baik.

Covid-19 berhasil mengubah kebiasaan yang kita lakukan sehari - hari baik di rumah, di sekolah, di tempat kerja, di jalan, dan dimanapun (Thorik, 2020). Pada kondisi pandemi COVID-19, sangat penting melakukan pendekatan pada publik dalam meningkatkan pengetahuan atas potensi risiko dan ancaman masalah kesehatan sehingga dapat memutuskan langkah - langkah dan tindakan yang dapat melindungi diri mereka terhindar dari paparan covid 19, yaitu dengan menerapkan protocol kesehatan (Supinganto et al., 2021). Mengingat bahayanya covid-19 dan pentingnya upaya memutus rantai penyebarannya, maka perlu adanya langkah nyata dari masyarakat dengan menerapkan protocol kesehatan sesuai anjuran pemerintah, yaitu: 1) sering cuci tangan; 2) gunakan masker; 3 ) menjaga jarak; 4) menjaga kesehatan (Nasruddin \& Haq, 2020).

\section{DESAIN PENELITIAN}

Tahapan Pelaksanaan langkah-langkah kegiatan:

a. Sosialisasi pelaksanaan Pendidikan kesehatan ini ditujukan dalam memastikan kesiapan tempat dan sasaran yang ada pada mitra sebagai gambaran awal tempat kegiatan.

b. Koordinasi dengan Kepala Desa Nambakor Kabupaten Sumenep. Pemberian pengarahan dan materi kepada remaja dan keluarga berencana di Desa Nambakor Kabupaten Sumenep.

c. Koordinasi dengan Ketua Organisasi Perkumpulan Kelompok Wanita Tani di Desa Saronggi.

d. Penyiapan Sarana dan Prasarana Penyuluhan

e. Persiapan Sarana dan prasarana yang pada kegiatan ini meliputi perlengkapan tikar, banner, laptop, proyektor

f. Pelaksanaan kegiatan pengabdian yaitu kegiatan ini dilaksanakan bertahap, Tahap 1 memberikan penyuluhan tentang protocol Kesehatan yaitu menggunakan masker, mencuci tangan dengan sabun dan air mengalir, menjaga jarak, menjauhi kerumunan.

g. Tahap 2 melakukan pendampingan tentang tatacara protocol kesehatan secara benar yaitu memberikan pelatihan cara mencuci tangan yang benar dengan menggunakan sabun dan air mengalir.

h. Evaluasi kegiatan meliputi kesiapan kegiatam, proses peyampaian materi, antusias kelompok wanita tani dalam mengikuti kegiatan dan pemahaman responden. 


\section{HASIL PENELITIAN}

Hasil kegiatan penyuluhan penerapan protocol kesehatan di salah satu rumah anggota kelompok wanita tani di ikuti \pm 60 orang di desa Saronggi Kabupaten Sumenep. Dari kegiatan yang telah dilaksanakan dan dikemas dalam bentuk penyuluhan dan pendampingan terdapat beberapa hasil evaluasi yaitu:

a. Evaluasi Struktur

Semua anggota Perkumpulan Kelompok Wanita Tani bekerja sama dengan baik dan kooperatif, hal tersebut dengan antusoas dan kooperatifnya anggota perkumpulan pada saat mempersiapkan sarana dan prasarana yang dibutuhkan pada kegiatan penyuluhan dan pendampingan .

b. Evaluasi Proses

Pada saat acara penyuluhan berlangsung, semua anggota perkumpulan kelompok wanita tani tampak fokus mendengarkan dan aktif bertanya apabila ada hal yag kurang dipahami.

c. Evaluasi Hasil

Pada saat tahap kedua yaitu pendampingan penerapan protocol kesehatan semua anggota Perkumpulan Kelompok wanita Tani sebanyak 60 orang mengikuti arahan dari pemateri. Dan semua anggota cukup cekatan dalam mengikuti arahan dari pemateri. Sebanyak 56 orang anggota tani memahami tentang materi yang telah dijelaskan dan dapat melakukannya secara madiri. Sedangkan 4 orang lainnya masih harus dibantu dalam melakukan penerapan protocol Kesehatan selama masa pandemi Covid-19.

d. Keberlanjutan

Bagi anggota Perkumpulan Kelompok Wanita Tani perlu tetap menjaga, melakukan dan tetapn disiplin melaksanan protocol kesehatan disaat kegiatan berlangsung. Dan diharapakan bisa memberikan informasi pada masyarakat umum untuk ikut melaksanakan penerapan protocol kesehatan

\section{PEMBAHASAN}

Berdasarkan hasil kegiatan penyuluhan tentang "Pendampingan penerapan Protokol kesehatan di masa era new normal pada perkumpulan kelompok wanita Tani di Desa Saronggi" berdampak positif khususnya pada Ibu beserta keluarga dan masyarakat luas pada umumnya. Dalam menangani penyebaran Covid-19 maka perlu dilakukan upaya preventif pada masyarakat (Suprayitno et al., 2020). Hasil penelitian Sari dan Atiqoh (2020) menyatakan bahwa ada hubungan antara pengetahuan masyarakat dengan kepatuhan penggunaan masker sebagai upaya pencegahan penyakit Covid-19.

Sejalan dengan hasil penelitian tersebut, maka diperlukan adanya upaya edukasi bagi masyarakat terkait pencegahan Covid-19 di antaranya melalui kebiasaan menggunakan masker (Supinganto et al., 2021). Salah satu cara preventif yaitu dengan melakukan kegiatan promosi kesehatan yang dilakukan melalui sosialisasi, edukasi, dan penggunaan berbagai media informasi untuk memberikan pemahaman terkait bahaya dan penularan Covid-19 Persepsi manfaat berpengaruh terhadap kepatuhan protokol kesehatan. Hasil tersebut sejalan dengan penelitian sebelumnya yang menyatakan bahwa persepsi manfaat memiliki hubungan dengan perubahan perilaku untuk mematuhi protokol kesehatan serta hasil penelitian tersebut menunjukkan bahwa persepsi manfaat yang tinggi berhubungan dengan 
tingkatkepatuhan dalam melaksanakan protokol kesehatan yang semakin baik pula (Afro et al., 2020)

\section{KESIMPULAN DAN SARAN}

Pendampingan penerapan Protokol kesehatan di masa era new normal pada perkumpulan kelompok wanita Tani di Desa Saronggi berjalan dengan lancar dan sesuai dengan harapan. Kegiatan yang dilakukan dengan 2 tahap ini diterima dengan sangat baik oleh anggota kelompok wanita tani. Kegiatan ini dianggap sangat positif dan sangat penting untuk kesehatan dan keselamatan semua masyarakat umum.

Semua anggota tetap disiplin melaksnakan protocol kesehatan di setiap kegiatan. Baik kegiatan pengajian dan kegiatan sehari - hari saat melakukan interaksi di tempat umum. Bagikan semua informasi yang di dapat kepada semua keluarga, tetangga dan masyarakat umum

\section{UCAPAN TERIMA KASIH}

Terimakasih kami sampaikan kepada seluruh pihak yang telah membantu dan mendukung acara pengabdian ini sehingga kegiatan dan artikel ini bisa terselesaikan. Semoga bisa bermanfaat untuk masyarakat luas dalam mencapai kesehatan yang optimal.

\section{DAFTAR RUJUKAN}

Afro, R. C., Isfiya, A., \& Rochmah, T. N. (2020). ANALISIS FAKTOR YANG MEMPENGARUHI KEPATUHAN TERHADAP PROTOKOL KESEHATAN SAAT PANDEMI COVID-19 PADA MASYARAKAT JAWA TIMUR: PENDEKATAN HEALTH BELIEF MODEL. Journal of Community Mental Health and Public Policy, 3(1), 1-10.

Nasruddin, R., \& Haq, I. (2020). Pembatasan Sosial Berskala Besar (PSBB) dan Masyarakat Berpenghasilan Rendah. SALAM: Jurnal Sosial Dan Budaya Syar-I, 7(7). https://doi.org/10.15408/sjsbs.v7i7.15569

Putri, R. S., Purwanto, A., Pramono, R., Asbari, M., Wijayanti, L. M., \& Hyun, C. C. (2020). Impact of the COVID-19 pandemic on online home learning: An explorative study of primary schools in Indonesia. International Journal of Advanced Science and Technology, 29(5), 4809-4818.

Rosidah, A., Khasanah, B. A., \& Kayis, R. (2020). meningkatkan kesadaran masyarakat terhadap pencegahan covid 19 melalaui video edukasi penerapan protokol kesehatan. 4(2), 414-419.

Suprayitno, E., Khoiriyati, A., \& Hidayati, T. (2017). Gambaran Efikasi Diri dan Peak Expiratory Flow Rate Pasien Penyakit Paru Obstruksi Kronis (PPOK). Media Ilmu Kesehatan, 6(1), 38-45.

Suprayitno, E., \& Wahid, A. (2019, November). Pendampingan Tentang Penyakit Hipertensi Dan Perawatan Keluarga Dengan Hipertensi. In Seminar Nasional Hasil Pengabdian Kepada Masyarakat (Vol. 3, No. 1, pp. 104-106). 
Suprayitno, E., Rahmawati, S., Ragayasa, A., \& Pratama, M. Y. (2020). Pengetahuan dan Sikap Masyarakat dalam Pencegahan COVID-19. Journal Of Health Science (Jurnal Ilmu Kesehatan), 5(2), 68-73.

Supinganto, A., Pramana, C., Sirait, L. I., Kumalasari, M. L. F., Hadi, M. I., Ernawati, K., Staryo, N. A., Suprayitno, E., Utami, K., \& Hadi, S. P. I. (2021). The Use of Masks, as an Effective Method in Preventing the Transmission of the COVID-19, During Pandemic and the New Normal Era: A Review. Kusniyati and Hadi, Selasih Putri Isnawati, The Use of Masks, as an Effective Method in Preventing the Transmission of the COVID-19, During Pandemic and the New Normal Era: A Review (February 7, 2021).

Thorik, S. H. (2020). Efektivitas Pembatasan Sosial Berskala Besar Di Indonesia Dalam Penanggulangan Pandemi Covid-19. Jurnal Adalah: Buletin Hukum Dan Keadilan, 4(1), 115-120.

Wiranti, W., Sriatmi, A., \& Kusumastuti, W. (2020). Determinan kepatuhan masyarakat Kota Depok terhadap kebijakan pembatasan sosial berskala besar dalam pencegahan COVID-19. Jurnal Kebijakan Kesehatan Indonesia: JKKI, 9(3), 117124. 